Raf. J. Sci., Vol. 24, No.2 pp. 65-81, 2013------

\title{
Separation of Lipoxygenase and Estimation of its Level in Blood of Males with Cardiovascular Disease
}

\author{
Ameera A. Mahmood \\ Department of Chemistry \\ College of Education \\ University of Mosul \\ Email : ameeraaziz 2000@yahoo.com
}

(Received 7/6/2012 ; Accepted 8/10/2012)

\begin{abstract}
The lipoxygenase (LOX) can influence the risk of cardiovascular disease (and diabetes) by virtue of its effect on lipid metabolism. Therefore, the present study deals with the separation and estimation of the level of LOX in blood of males with cardiovascular disease (only /or in addition to diabetes).

The enzyme was separated and purified from the blood-cells homogenate by precipitation (using 0-55\% ammonium sulfate), dialysing against the buffer solution and then by applying ion exchange chromatography, when three bands were distinguished. The enzyme showed different specific activities in the elution of these bands and the highest activity was for the second band. Concerning the characterization of enzyme, it has been found that the optimum condition of the enzyme was at $\mathrm{pH} 8,40^{\circ} \mathrm{C}$ and the enzyme has $\mathrm{km}=1.99 \mathrm{mM}$ at $12 \mathrm{mM}$ of the substrate (linoleate) concentration.

The results showed that the incidence of cardiovascular disease and diabetes led to a significant increase in the level of LOX in both the blood-cells homogenate and the serum.

The study also focused on assessing the serum total cholesterol (TC), high density lipoprotein-cholesterol (HDL-C), glutathione (GSH) and malondialdehyde (MDA). The results indicated that there was a significant increase in the level of TC and MDA and there was a significant decrease in the level of HDL-C and GSH in addition to an increase in the ratio of TC/HDL-C.

On the basis of the results, it may be concluded that the LOX in blood cells has more than one isoenzyme with different activities. In addition, the high level of LOX is considered as a negative indicator that promotes cardiovascular disease and diabetes.
\end{abstract}

Keywords : lipoxygenase, cardiovascular disease, diabetes. 


\section{فمل أنزجم اللايبوكسيجنيز وقدير مستولف م النكور المصلبين بأمرالن الأوعية الموبة}

\section{الملضص}

لأنزيم اللايبوكسيجنيز علاقة بلحتمالية الإصابة بأمراض الأوعية الموية وللسكري من خلال علاقته وتأثيره

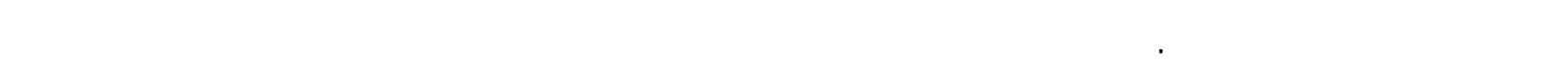

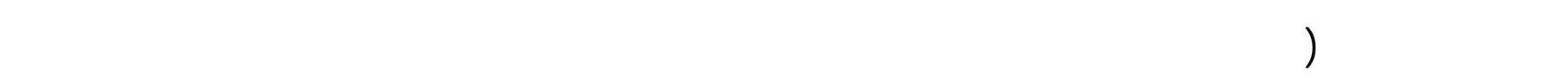

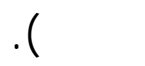

مق فصل وتقية الأنزيم من متجانس خلايا الدم من خلال ترسيبه بكبريتات الأمونيوم بدرجة تشنع 0-55\%

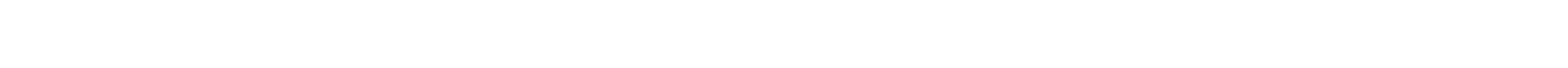

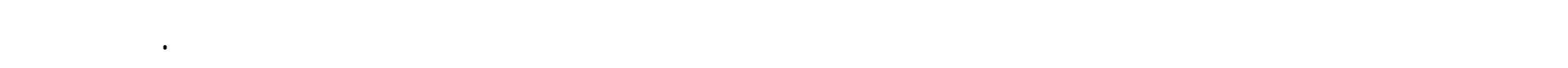

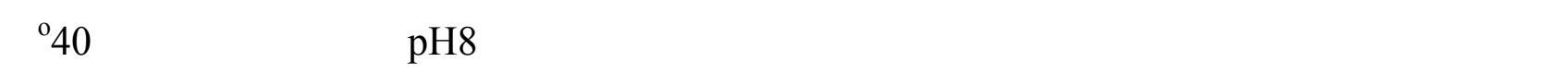

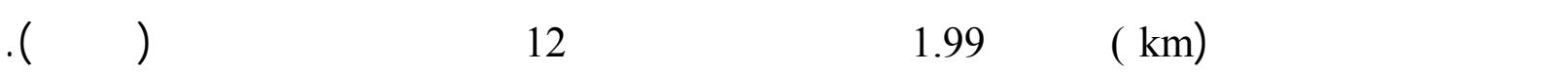

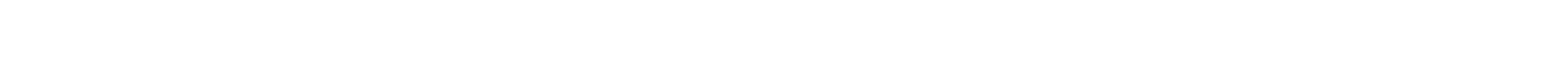

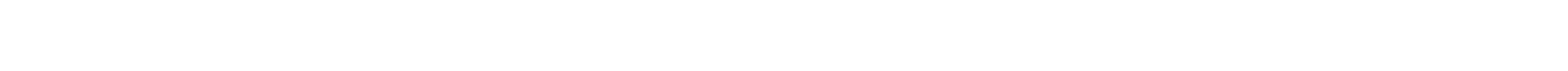

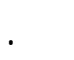

اهتمت الدرلسة أيضأ بققير مستوى بعض المتغيرات الكيموحيوية (الكوليستيرول الكلي وكوليستيرول

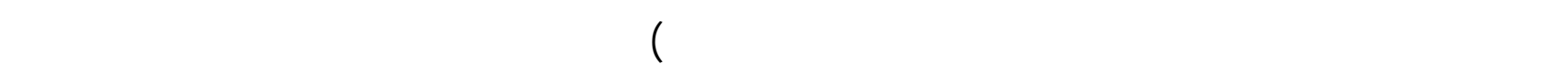

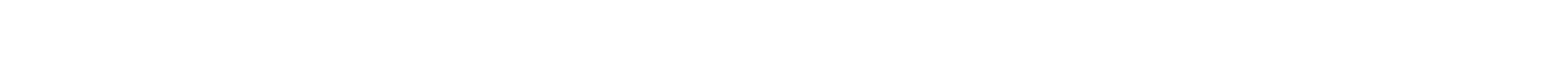

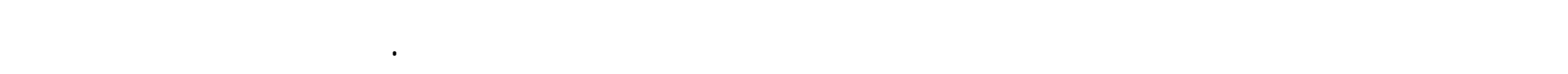

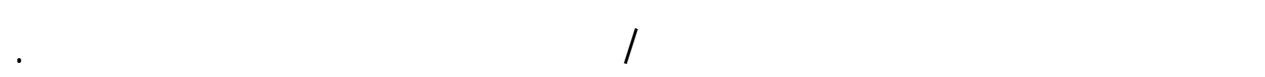

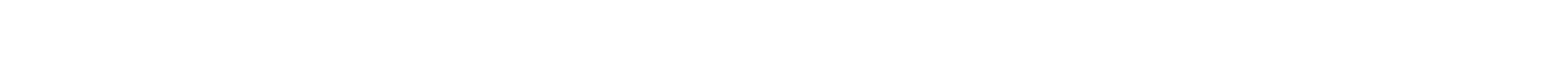

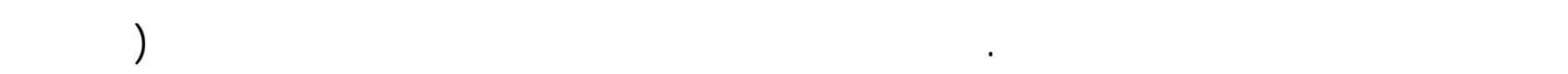

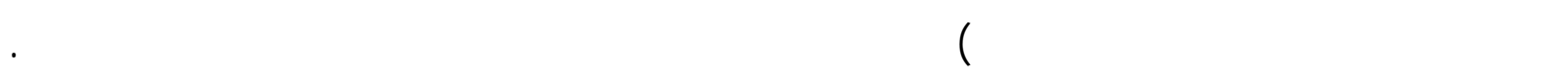
الكاملت الدالة : أنزيم اللايبوكسيجنيز، أمراض الأوعية الموية، داء للسكري. 


\section{INTRODUCTION}

Metabolic syndrome, which includes a number of systemic clinical and biochemical processes (insulin resistance, abdominal obesity, hypertension and dyslipidemia) attracts the attention of endocrinologists and cardiologists. This is due to the large spread of this syndrome in the population and its effect on the development of cardiovascular disease and diabetes mellitus type 2 (Novgorodtseva et al., 2011).

Leukotrienes (LTs) are potent lipid mediators of inflammatory responses and have been implicated in the pathophysiology of acute and chronic inflammatory diseases including asthma, arthritis, psoriasis and inflammatory bowel disease (Maskrey and O'Donell, 2008). LTs are one type of eicosanoids that are produced from lipid peroxidation of 20-carbon (eicosa-) polyunsaturated fatty acids. They are generated in biological systems by lipoxygenases, LOXs (Murphy and Gljon, 2007).

LOXs are a family member of non-heme iron-containing dioxygenase that catalyze the step of conversion of arachidonic acid to 12 and 15-hydroxy eicosatetraenoic acid (12-HETE and 15-HETE ) (Radmark et al., 2007). The 12/15 LOX was originally isolated from porcine leukocytes, but its tissue distribution is now known to be relatively wide, including blood vessels, brain, skin and kidneys. Several lines of evidence have suggested that 12/15-LOX may play an important role in the development of atherosclerosis, diabetes and neurodegenerative disease (Spanbrock et al., 2003).

The LTs family is divided into two classes, the classical chemoattractant $\mathrm{LTB}_{4}$ and spasmogenic cysteinyl LTs such as $\mathrm{LTC}_{4}, \mathrm{LTD}_{4}$ and $\mathrm{LTE}_{4}$. The LTs are involved in chronic inflammatory disease, including atherosclerosis, myocardial infarction and stroke (Chabane et al., 2009). The peptidyl LT and $\mathrm{LTB}_{4}$ increase the adhesion of leukocytes to endothelial cell (Maskrey and O'Donell, 2008). The LTs are predominantly synthesized by inflammatory cells, such as polymorphonuclear leukocytes, macrophages and mast cells (Huo et al., 2004).

In addition to lipoxygenase, other variables have been found to be useful for detecting cardiovascular disease and diabetes. Both produce disturbances of lipid profiles, especially an elevation in the level of LDL-cholesterol and a decrease in the level of HDL-cholesterol, the major risk factors of coronary artery disease (Riendeau et al., 1991).

Diabetes and cardiovascular disease increase susceptibility to lipid peroxidation. An increased oxidative stress has been observed as indicated by high free radical production. The measuring of serum antioxidants and malondialdehyde ( the end product of lipid peroxidation) would provide an index of oxidative stress (Willams and Harwood, 2000). One of the most important endogenous antioxidants that counter the effect of free radicals is glutathione. It plays the role of a sulfhydryl group (SH) provider for direct scavenging reactions (Kayama et al., 2009).

The present work aims to separate the lipoxygenase from the blood cells-homogenate. It also aims to investigate the relation between the level of lipoxygenase, total cholesterol (TC), high density lipoprotein-cholesterol (HDL-C), malondialdehyde (MDA) and glutathione (GSH) in the serum (in addition to the level of lipoxygenase in blood cells-homogenate) and the 
probability of causing vascular disease and diabetes taking into consideration the age of the subjects and whether or not they are smokers.

\section{MATERIALS AND METHODS}

The subjects were divided into two main groups: a healthy group ( 72 males) and a patient group ( 83 males). Of the patient group, 55 subjects had cardiovascular disease only and 28 subjects had diabetes millitus in addition to cardiovascular disease. All patients were residents in the Care Unit in Ibn Seena Teaching Hospital, Mosul. Then, each group is divided into three age categories (20-34، 35-49 and $\geq 50 \mathrm{y}$ ) taking in to consideration whether/ or not the subjects were smokers.

\section{Blood sampling}

At the approval of Hospital management, blood samples were drawn from all subjects into plain plastic tubes and the serum was separated $2 \mathrm{~h}$ after venipuncture by centrifugation.

\section{Separation of lipoxygenase from blood-cells homogenate}

The precipitated blood-cells produced after centrifugation of blood samples were washed three times with isotonic saline and haemolysed in twice the volume of distilled water. The haemolysate was cautiously adjusted to $\mathrm{pH} 6$ by adding $1 \mathrm{M} \mathrm{HCl}$. The stroma was removed by centrifugation at $2000 \times \mathrm{g}$ for $20 \mathrm{~min}$. In the preparative experiments, $5 \mathrm{mM}$ mercaptoethanol was added in order to stabilize the enzyme. Ammonium sulfate was added to the supernatant and the precipitate, produced at 55\% saturation, dissolved in water and then dialyzed against $0.003 \mathrm{M}$ Tris- $\mathrm{HCl}$ at pH7.2 using the semipermeable membrane, cellophane (Rapoport et al., 1979).

Further enrichment was achieved by anion-exchange chromatography on DEAE-cellulose, which removed the residul haemogllobin (Lowenstein, 1981). A column with $40 \times 2.5 \mathrm{~cm}$ diameters, supplied from Pharmacia Fine Chemicals, was used.

\section{Characterization of lipoxygenase}

In order to find the optimum $\mathrm{pH}$, the activity of the purified lipoxygenase was determined by using Tris- $\mathrm{HCl}$ buffers with a range of $\mathrm{pH}$ value (5-10), and in order to find the optimum temperature, the activity of the purified enzyme was determined by using a range of different temperatures $\left(4-90^{\circ} \mathrm{C}\right)$.

Michael's constant, km, of lipoxygenase was determined by carrying out the reaction using substrate (linoleate) solutions with different concentrations ranging between 0-14 mM.

\section{Assay method}

The activity of lipoxygenase to convert linoleate to its hydroperoxide was assayed by Holman method (Rapoport et al., 1979).

The protein level in the studied solutions (accept the serum ) was assayed by a modified Lowary method (Scharcterle and Pollack, 1973).

\section{Estimation of biochemical parameters}

The serum total cholesterol (TC) and high density lipoprotein-cholesterol (HDL-C) were analyzed enzymatically using a commercial reagent (Kits) obtained from Fortress, U.K.

Al-Zamely et al's modified method (2001) was used to estimate the concentration of serum glutathione which depends on the reduction of disulfide bond of 5, 5'-dithio-bis-2nitrobenzoic acid (DTNB) by the sulfhydryl group of glutathione. 
The formation of malondialdehyde (MDA) was determined by the thiobarbituric acid method (Akande and Akinyinka, 2005).

\section{Statistical analysis}

For comparison between more than two groups, Duncan multiple range test was used. All the data were expressed as mean \pm S.D. of the mean. Different letters indicate a significant difference at $\mathrm{p} \leq 0.05$ level.

\section{RESULTS AND DISCUSSION}

\section{Separation of lipoxygenase from blood-cells homogenate}

As stated before, several experiments have been applied to separate lipoxygenase from blood-cells homogenate. The separation methods used are based on the differences in the molecular size, charge and hydrophobic affinity. After each experiment, the total protein, total activity and specific activity were determined. The specific activity was taken into consideration.

As shown in table 1, the specific activity of lipoxygenase in the initial homogenate was $0.854 \mathrm{U} / \mathrm{mg}$ protein. After precipitation by ammonium sulfate, it was raised to $1.253 \mathrm{U} / \mathrm{mg}$ protein, i.e. it was multiplied by 1.468 folds compared with that of initial homogenate. Dialysis increased the specific activity of the enzyme up to $1.973 \mathrm{U} / \mathrm{mg}$ protein or it was multiplied by 2.31 folds.

The ion exchange chromatography was applied to the residue obtained from dialysis. During the elution with $0.03 \mathrm{M}$ Tris- $\mathrm{HCl}$ at $\mathrm{pH} 7.2$, three well defined-lipoxygenase bands have been appeared (Fig.1) and they showed different specific activities; 2.949, 5.733 and 3.435 $\mathrm{U} / \mathrm{mg}$ protein for band I, II and III respectively.

\section{Table 1: Separation of lipoxygenase from blood-cells homogenate}

\begin{tabular}{|c|c|c|c|c|c|c|}
\hline Fraction & $\begin{array}{c}\text { Volume } \\
\text { (ml) }\end{array}$ & $\begin{array}{c}\text { Total protein } \\
\text { (mg) }\end{array}$ & $\begin{array}{c}\text { Total } \\
\text { activity } \\
\text { (units) }\end{array}$ & $\begin{array}{c}\text { Specific } \\
\text { activity } \\
\text { (units/mg } \\
\text { protein) }\end{array}$ & $\begin{array}{c}\text { Purification } \\
\text { fold }\end{array}$ & $\begin{array}{c}\text { Yields } \\
\text { \% }\end{array}$ \\
\hline $\begin{array}{c}\text { Blood-cells } \\
\text { Homogenate }\end{array}$ & 15 & 9.435 & 8.055 & 0.854 & 1 & 100 \\
\hline $\begin{array}{c}\text { Precipitation } \\
\text { by (0-55\%) } \\
\text { ammonium sulfate }\end{array}$ & 12 & 7.2 & 9.024 & 1.253 & 1.468 & 112.0298 \\
\hline Dialysis & 13.5 & 5.4 & 10.6515 & 1.973 & 2.310 & 132.2346 \\
\hline $\begin{array}{c}\text { Ion-exchange } \\
\text { (DEAE-Cellulose) }\end{array}$ & & & & & & \\
\hline band I & 60 & 2.865 & 8.448 & 2.949 & 3.454 & 104.879 \\
\hline band II & 40 & 0.72 & 4.128 & 5.733 & 6.716 & 71.95531 \\
\hline band III & 45 & 1.6875 & 5.796 & 3.435 & 4.023 & 51.24767 \\
\hline
\end{tabular}

* $\mathrm{U}$, the amount of enzyme that produce $1 \mu \mathrm{M}$ of product per minute.

** $\mathrm{U} / \mathrm{mg}$, the number of enzyme units per milligram of protein. 


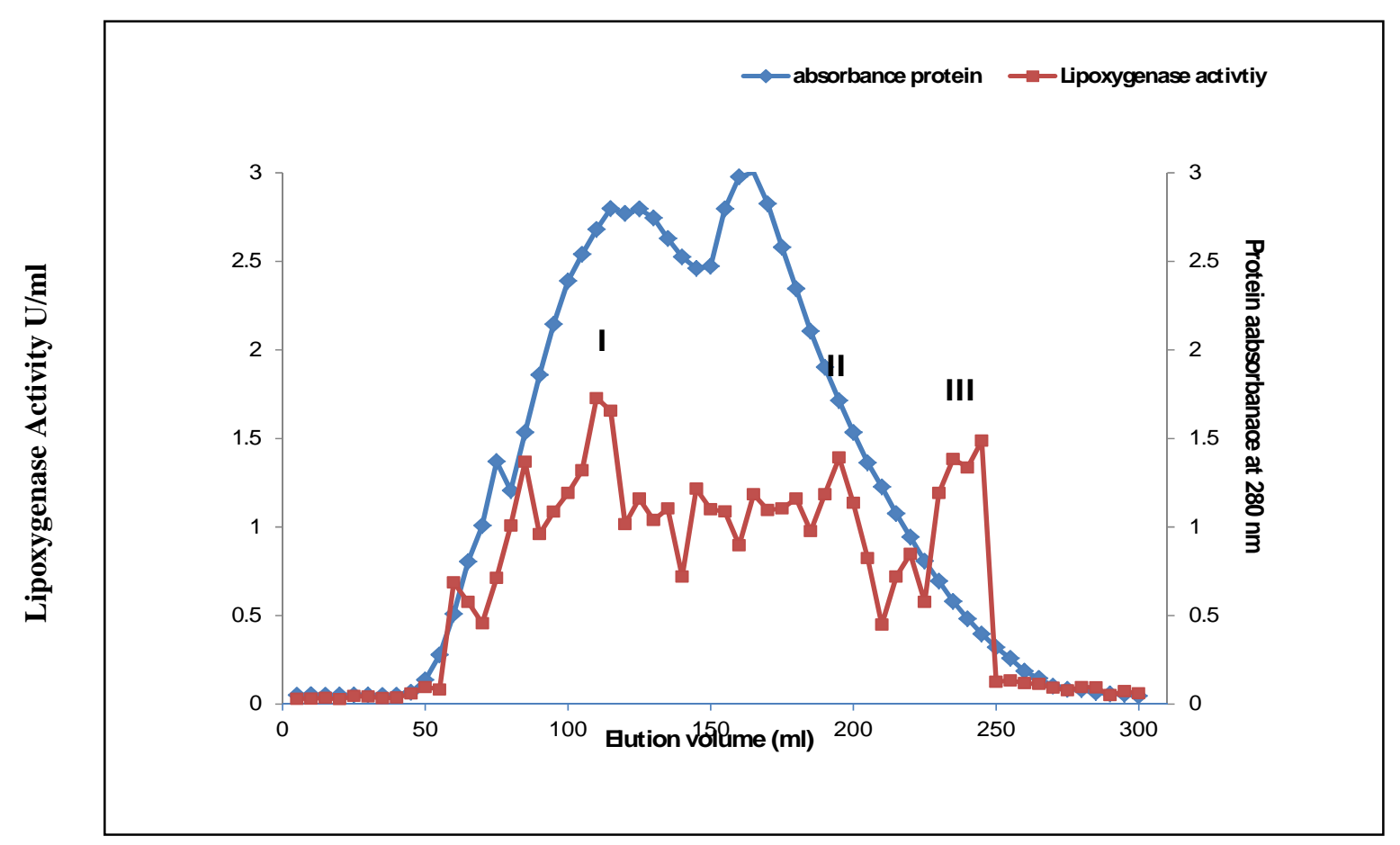

Fig. 1: Elution profile of protein and lipoxygenase activity from the purification of the enzyme on DEAE-cellulose by applying ion-exchange chromatography.

It was stated that the lipoxygenase of human blood-cells was soluble enzyme. However, when subjected to centrifugation at $100000 \times \mathrm{g}$ for $1 \mathrm{~h}$, only $30-60 \%$ of the initial activity could be recovered in the supernatant. In addition, $40-60 \%$ of the enzymatic activity in the purified preparation was lost upon standing in the chromatography buffer at $0^{\circ} \mathrm{C}$ for $30 \mathrm{~min}$ (Rouzer and Samuelsson, 1985). This indicates that the purification of the human lipoxygenase would be extremely difficult.

On the other hand, maximal enzymatic activity is clearly dependent on the presence of stimulating factors such as $\mathrm{Ca}^{2+}$ and ATP. Also, glutathione and mercaptoethanol protect lipoxygenase activity and the later is much more effective (Rapoport et al., 1979), hence it was added to the blood-cells homogenate to achieve this purpose.

As shown in Table (1), the specific activity of lipoxygenase in the blood-cells homogenate has been increased by 1.468 and 2.310 folds after separation by ammonium sulphate precipitation and dialysis, respectively comparing with its activity in the initial homogenate.

More than one band has been obtained in case of applying ion-exchange chromatography (Fig. 1) with different activities suggesting microheterogeneity (Rouzer and Samuelsson, 1985). The second band exhibited the higher activity, it increased by 6.716 folds. This indicates the presence of more than one isoenzyme and the more active form, toward linoleate at $\mathrm{pH} 9$ and $37^{\circ} \mathrm{C}$, has been presented in the second band-elution produced by applying ion exchange chromatography using DEAE-cellulose. 


\section{Characterization of lipoxygenase}

This study has dealt with the characterization of lipoxygenase appearing in the elution of band II produced from ion-exchange chromatography.

The effect of $\mathrm{pH}$ (using Tris-HCl buffer) on the activity of lipoxygenase is shown in Fig 2. The top of the curve shows that the optimum $\mathrm{pH}$ of the enzyme activity was to be at $\mathrm{pH} 8$, with the activity falling off symmetrically on both sides.

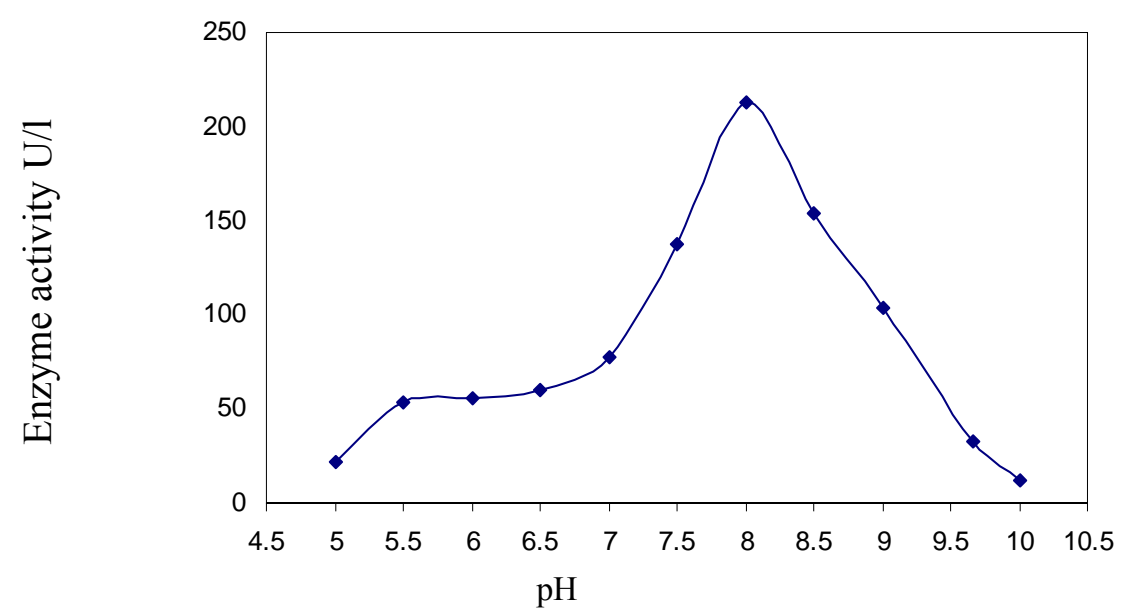

Fig.2: Effect of pH on lipoxygenase activity using Tris-HCI buffer.

The catalytic mechanism of the enzymes is largely due to the fact that its active sites possess structures which are uniquely suited to promote catalysis. Several factors contribute to enzyme catalysis and one of the most important of these factors is the $\mathrm{pH}$ which plays on important role in the formation, maintenance or disturbance of the three-dimensional structure of the enzyme molecule or its active site (McKee and McKee, 1996). Each enzyme has its own optimum $\mathrm{pH}$ to reach the maximum velocity and the optimum $\mathrm{pH}$ is not necessarily the best $\mathrm{pH}$ for physiological control in vivo (Christenson et al., 2001).

Figure 3 exhibited the effect of temperature on the activity of lipoxygenase. The top of the curve shows that the optimum temperature of the enzyme activity was to be at $40^{\circ} \mathrm{C}$, with the activity falling off symmetrically on both sides.

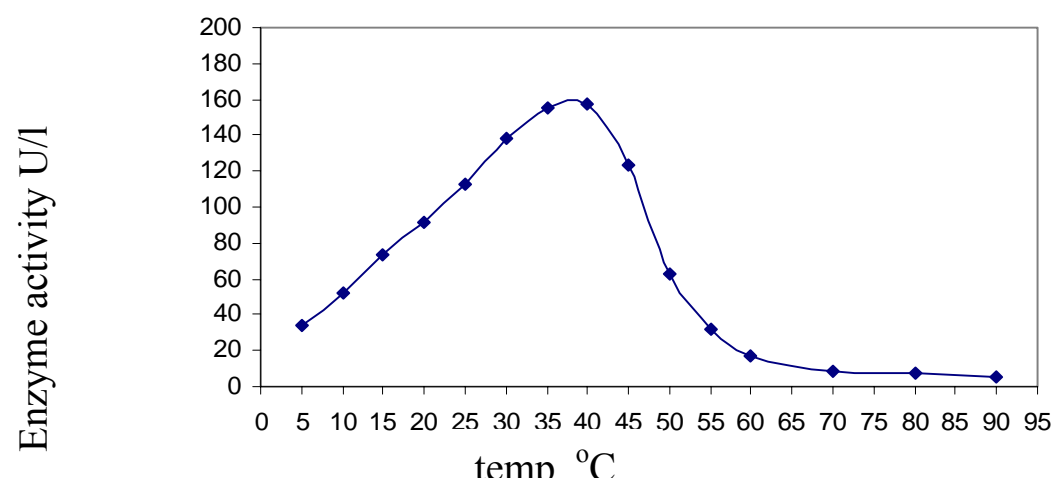

Fig.3: Effect of temp. on lipoxygenase activity. 
Increasing the temperature results in an increase in enzyme activity until the optimum temperature is reached, above which any increase in temperature results in a decrease in enzyme activity. The sudden loss of enzyme activity that occurs at temperatures above the optimum temperature is due to thermal denaturation. Most enzymes are inactivated at $55-60{ }^{\circ} \mathrm{C}$ (Christenson et al., 2001).

This study has also dealt with the estimation of lipoxygenase affinity toward linoleate through the determination of $\mathrm{km}$ of its reaction. As shown in Fig. 4, the highest activity was encountered at $12 \mathrm{mM}$ substrate (linoleate) concentration, so $\mathrm{Km}$ was $1.8 \mathrm{mM}$ (applying Michael-Menten equation) and $1.99 \mathrm{mM}$ (applying Lineweaver-Berk equation).
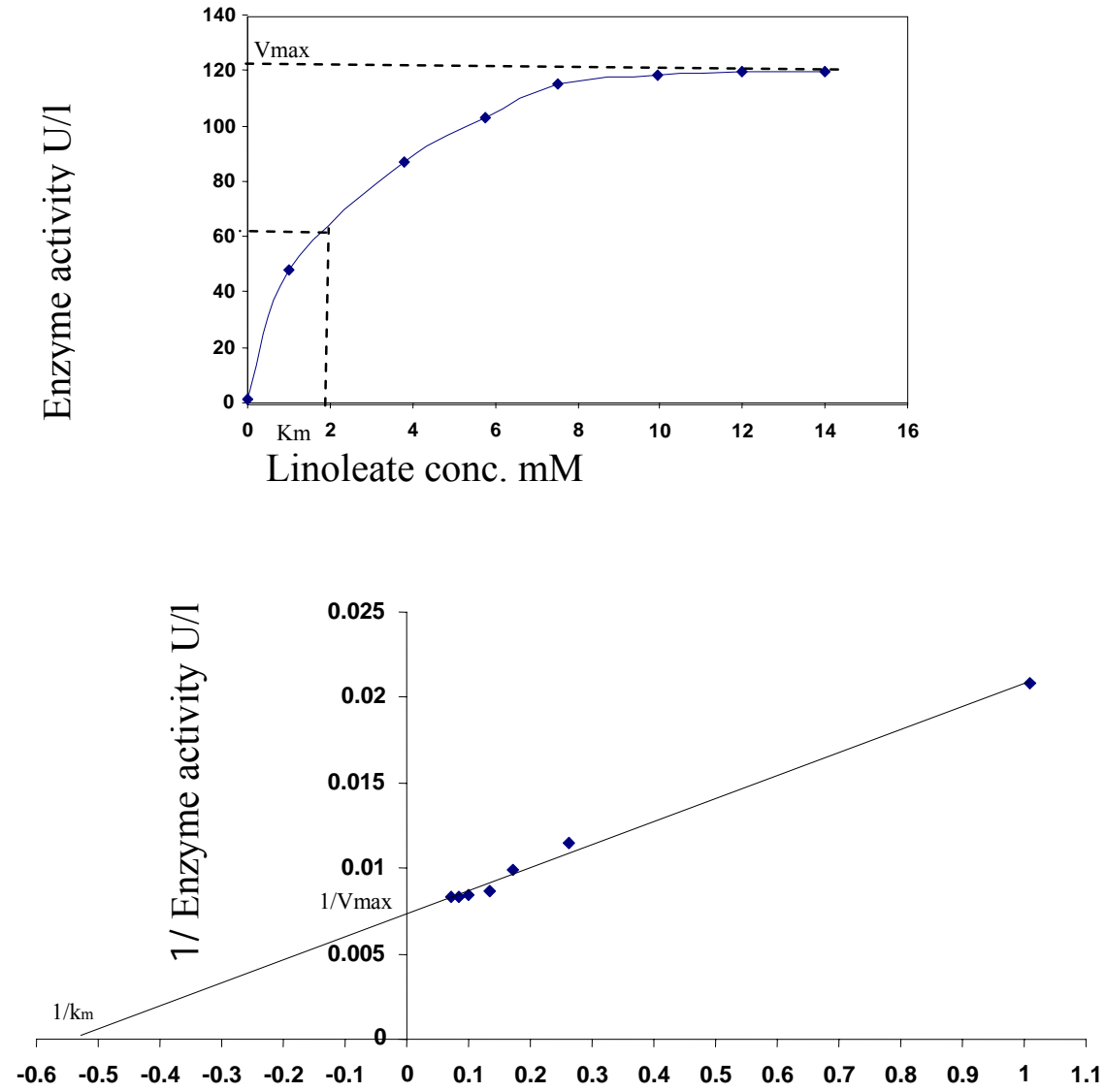

1/ Linoleate conc. $\mathrm{mM}$

Fig. 4: Effect of substrate conc. on lipoxygenase activity.

This result indicated that lipoxygenase has a high affinity toward linoleate, since the affinity is inversely proportional to $\mathrm{km}$-value and it is worth-noting that the $\mathrm{km}$-values of most of the enzymes are ranged between $10^{-1}-10^{-6} \mathrm{M}$ (Al-Flayeh, 2000). 


\section{Estimation of lipoxygenase level in serum and blood-cell homogenate}

The level of lipoxygenase in the serum and in the blood-cells homogenate of studied subjects are presented in Table (2) (I-VI). Compared with the healthy subjects, all subjects with cardiovascular disease, whether smokers or nonsmokers, exhibited a significant increase in the level of lipoxygenase in the serum and in the blood-cells homogenate. This result agrees with what Imig (2006) and Jawien and Korbut (2010) conclude; they state that the LOX is abundantly expressed in atherosclerosis lesions. The high expression of this enzyme in the lesions of animal atherosclerosis and humans, and its absence in normal vessel wall suggest its involvement in atherosclerosis (Imig, 2006 ; Kuhn et al., 1992).

There are numerous potential targets that could be useful in the intervention in LTmetabolism in atherosclerosis. The microsomal protein, five lipoxygenase activating protein (FLAP), was found to be critical for regulation of 5-LOX activity and biosynthesis of LTs within certain compartments of plasma membrane. The genetic polymorphisms of FLAP are associated with myocardial infarction and stroke by increasing LT production and inflammation in the arterial wall (Helgadottir et al., 2004). In advanced human atherosclerotic lesions, the hydroxy linoleic acid/ linoleic acid ratio is much higher and may be used as a reliable parameter to quantify the degree of oxidative modification which reflects the level of LOXs (Kuhn et al., 1992).

Table 2: The level of the lipoxygenase and some biochemical variables in male blood.

\begin{tabular}{|c|c|c|c|}
\hline \multicolumn{4}{|c|}{ I Nonsmokers aged 20-34 y } \\
\hline \multirow[b]{2}{*}{ Parameters } & \multicolumn{3}{|c|}{ Mean \pm S.D. } \\
\hline & $\begin{array}{c}\text { Control } \\
\mathbf{n}=11\end{array}$ & $\begin{array}{c}\text { Cardiovascular } \\
\text { Patients } \\
n=6\end{array}$ & $\begin{array}{l}\text { Diabetic Patients } \\
\text { n=0(not obtained) }\end{array}$ \\
\hline $\begin{array}{l}\text { LOX level in the serum*** } \\
\text { U/I }\end{array}$ & $188.5 \pm \frac{13.03}{\mathrm{~B}}$ & $\begin{array}{c}286.50 \pm 8.66 \\
\mathrm{~A}\end{array}$ & - \\
\hline $\begin{array}{l}\text { LOX level in the blood- } \\
\text { cells homogenate*** U/l }\end{array}$ & $\begin{array}{c}300 \pm 21.5 \\
\mathrm{~B}\end{array}$ & $\begin{array}{c}516.0 \pm 28.3 \\
\mathrm{~A}\end{array}$ & - \\
\hline $\begin{array}{c}\text { TC level*** } \\
\text { mg/100 ml }\end{array}$ & $\begin{array}{c}140.0 \pm 21.8 \\
\mathrm{~B}\end{array}$ & $\begin{array}{c}161.77 \pm 6.85 \\
\mathrm{~A}\end{array}$ & - \\
\hline $\begin{array}{l}\text { HDL-C level* } \\
\text { mg/100 ml }\end{array}$ & $\begin{array}{c}58.159 \pm 4.524 \\
\mathrm{~A}\end{array}$ & $\begin{array}{c}50.6 \pm 7.1 \\
\mathrm{~B}\end{array}$ & - \\
\hline TC/HDL-C** & $3.06 \pm 0.85$ & $\begin{array}{c}3.90 \pm 0.62 \\
\mathrm{~A}\end{array}$ & - \\
\hline $\begin{array}{c}\text { GSH level*** } \\
\mu \mathrm{M} / \mathrm{l}\end{array}$ & $\begin{array}{c}16.93 \pm 7.34 \\
\mathrm{~A}\end{array}$ & $\begin{array}{c}7.88 \pm 2.46 \\
\mathrm{~B}\end{array}$ & - \\
\hline $\begin{array}{c}\text { MDA level* } \\
\mu \mathrm{M} / \mathrm{l}\end{array}$ & $\begin{array}{c}2.31 \pm 0.71 \\
\mathrm{~B}\end{array}$ & $\begin{array}{c}3.13 \pm 0.60 \\
\mathrm{~A}\end{array}$ & - \\
\hline
\end{tabular}


Ameera A. Mahmood and Rawya N. Rashed

\begin{tabular}{|c|c|c|c|}
\hline \multicolumn{4}{|c|}{ II Nonsmokers aged 35-49 y } \\
\hline \multirow[b]{2}{*}{ Parameters } & \multicolumn{3}{|c|}{ Mean \pm S.D. } \\
\hline & $\begin{array}{c}\text { Control } \\
\mathbf{n}=10\end{array}$ & $\begin{array}{c}\text { Cardiovascular } \\
\text { Patients } \\
n=6\end{array}$ & Diabetic Patients $n=8$ \\
\hline $\begin{array}{l}\text { LOX level in the } \\
\text { serum*** U/l }\end{array}$ & $\begin{array}{c}231.3 \pm 57.8 \\
\mathrm{C}\end{array}$ & $\begin{array}{c}367.2 \pm 78.9 \\
B\end{array}$ & $\begin{array}{c}533.5 \pm 79.3 \\
\mathrm{~A}\end{array}$ \\
\hline $\begin{array}{c}\text { LOX level in the } \\
\text { blood-cells } \\
\text { homogenate*** U/l }\end{array}$ & $541 \pm \frac{ \pm}{C} 137$ & $\begin{array}{c}975.2 \pm 19.4 \\
\mathrm{~B}\end{array}$ & $\begin{array}{c}1272 \pm 257 \\
\mathrm{~A}\end{array}$ \\
\hline $\begin{array}{l}\text { TC level*** } \\
\text { mg/100 ml }\end{array}$ & $166.99 \pm 70.05$ & $\begin{array}{c}213.53 \pm 18.47 \\
B\end{array}$ & $\begin{array}{c}228.75 \pm 15.5 \\
\mathrm{~A}\end{array}$ \\
\hline $\begin{array}{c}\text { HDL-C level*** } \\
\text { mg/100 ml }\end{array}$ & $\begin{array}{c}51.657 \pm 4.990 \\
\mathrm{~A}\end{array}$ & $\begin{array}{c}40.58 \pm 6.79 \\
\mathrm{~B}\end{array}$ & $\begin{array}{c}34.47 \pm 7.07 \\
\mathrm{C}\end{array}$ \\
\hline TC/HDL-C* & $\begin{array}{c}3.82 \pm 1.01 \\
\mathrm{~B}\end{array}$ & $\begin{array}{c}4.55 \pm 1.30 \\
\mathrm{~A}\end{array}$ & $\begin{array}{c}4.93 \pm 1.66 \\
\mathrm{~A}\end{array}$ \\
\hline $\begin{array}{c}\text { GSH level*** } \\
\mu \mathrm{M} / \mathrm{l}\end{array}$ & $\begin{array}{c}14.71 \pm 3.68 \\
\mathrm{~A}\end{array}$ & $\begin{array}{c}6.33 \pm 2.76 \\
\mathrm{~B}\end{array}$ & $\begin{array}{c}5.7300 \pm 1.83 \\
\mathrm{~B} \\
\end{array}$ \\
\hline $\begin{array}{c}\text { MDA level* } \\
\mu \mathrm{M} / \mathrm{l}\end{array}$ & $\begin{array}{c}2.88 \pm 1.061 \\
\mathrm{~B}\end{array}$ & $\begin{array}{c}3.71 \pm 2.39 \\
\mathrm{~A}\end{array}$ & $\begin{array}{c}4.1 \pm 1.29 \\
\mathrm{~A}\end{array}$ \\
\hline
\end{tabular}

\begin{tabular}{|c|c|c|c|}
\hline \multicolumn{4}{|c|}{ III Nonsmokers aged $\geq 50 \mathrm{y}$} \\
\hline \multirow[b]{2}{*}{ Parameters } & \multicolumn{3}{|c|}{ Mean \pm S.D. } \\
\hline & $\begin{array}{c}\text { Control } \\
\mathrm{n}=14\end{array}$ & $\begin{array}{c}\text { Cardiovascular } \\
\text { Patients } \\
\text { n=11 }\end{array}$ & Diabetic Patients $n=8$ \\
\hline $\begin{array}{l}\text { LOX level in the } \\
\text { serum** U/l }\end{array}$ & $\begin{array}{c}268.5 \pm 73.9 \\
\mathrm{C}\end{array}$ & $477 \pm 107$ & $\begin{array}{c}706 \pm 154 \\
\mathrm{~A}\end{array}$ \\
\hline $\begin{array}{l}\text { LOX level in the } \\
\text { blood-cells } \\
\text { homogenate*** U/I }\end{array}$ & $\begin{array}{c}580.40 \pm 170 \\
\mathrm{C}\end{array}$ & $\frac{1304 \pm 218}{B}$ & $\begin{array}{c}1756 \pm 280.4 \\
\mathrm{~A}\end{array}$ \\
\hline $\begin{array}{l}\text { TC level** } \\
\mathrm{mg} / 100 \mathrm{ml}\end{array}$ & $179.3 \pm 24.91$ & $221.5 \pm 33.23$ & $\begin{array}{c}248.01 \pm 45.3 \\
\mathrm{~A}\end{array}$ \\
\hline $\begin{array}{c}\text { HDL-C level** } \\
\text { mg/100 ml }\end{array}$ & $\begin{array}{c}46.080 \pm 3.779 \\
\mathrm{~A}\end{array}$ & $38.1 \pm \frac{2.20}{\mathrm{~B}}$ & $\begin{array}{c}33.8 \pm 2.8 \\
\mathrm{~B}\end{array}$ \\
\hline TC/HDL-C* & $\begin{array}{c}4.073 \pm 0.911 \\
\mathrm{~B}\end{array}$ & $\begin{array}{c}5.15 \pm 1.89 \\
\mathrm{~A}\end{array}$ & $\begin{array}{c}5.62 \pm 1.48 \\
\mathrm{~A}\end{array}$ \\
\hline $\begin{array}{c}\text { GSH level }^{* *} \\
\mu \mathrm{M} / \mathrm{l}\end{array}$ & $\begin{array}{c}13.40 \pm 2.42 \\
\mathrm{~A}\end{array}$ & $\begin{array}{c}5.63 \pm 1.47 \\
B\end{array}$ & $\begin{array}{c}4.646 \pm 0.719 \\
\mathrm{~B}\end{array}$ \\
\hline $\begin{array}{c}\text { MDA level* } \\
\mu \mathrm{M} / \mathrm{l}\end{array}$ & $\frac{3.66 \pm 0.55}{B}$ & $\frac{3.89 \pm 0.36}{\mathrm{~B}}$ & $\begin{array}{c}4.37 \pm 0.73 \\
\mathrm{~A}\end{array}$ \\
\hline
\end{tabular}




\begin{tabular}{|c|c|c|c|}
\hline \multicolumn{4}{|c|}{ IV smokers aged 20-34 y } \\
\hline \multirow[b]{2}{*}{ Parameters } & \multicolumn{3}{|c|}{ Mean \pm S.D. } \\
\hline & $\begin{array}{c}\text { Control } \\
\mathbf{n}=9\end{array}$ & $\begin{array}{c}\text { Cardiovascular } \\
\text { Patients } \\
\mathbf{n}=\mathbf{8}\end{array}$ & $\begin{array}{l}\text { Diabetic Patients } \\
\text { n=0(not obtained) }\end{array}$ \\
\hline $\begin{array}{l}\text { LOX level in the } \\
\text { serum** U/l }\end{array}$ & $\begin{array}{c}226.3 \pm 64.4 \\
B\end{array}$ & $\begin{array}{c}423 \pm 49.8 \\
\mathrm{~A}\end{array}$ & - \\
\hline $\begin{array}{l}\text { LOX level in the blood- } \\
\text { cells homogenate*** U/I }\end{array}$ & $\begin{array}{c}480 \pm 126.7 \\
\mathrm{~B} \\
\end{array}$ & $\begin{array}{c}844.0 \pm 139.6 \\
\mathrm{~A}\end{array}$ & - \\
\hline $\begin{array}{l}\text { TC level** } \\
\text { mg/100 ml } \\
\end{array}$ & $\begin{array}{c}151.7 \pm 20.5 \\
\mathrm{~B}\end{array}$ & $\begin{array}{c}180.4 \pm 15.9 \\
\mathrm{~A}\end{array}$ & - \\
\hline $\begin{array}{c}\text { HDL-C level** } \\
\text { mg/100 ml }\end{array}$ & $\begin{array}{c}50.12 \pm 6.72 \\
\mathrm{~A}\end{array}$ & $\begin{array}{c}40.6 \pm 8.1 \\
\mathrm{~B}\end{array}$ & - \\
\hline TC/HDL-C** & $\begin{array}{c}3.60 \pm 1.25 \\
\mathrm{~B}\end{array}$ & $\begin{array}{c}4.93 \pm 1.124 \\
\mathrm{~A}\end{array}$ & - \\
\hline $\begin{array}{c}\text { GSH level }^{* * *} \\
\mu \mathrm{M} / \mathrm{l}\end{array}$ & $\begin{array}{c}16.35 \pm 2.07 \\
\mathrm{~A}\end{array}$ & $\begin{array}{c}6.490 \pm 0.910 \\
\mathrm{~B}\end{array}$ & - \\
\hline $\begin{array}{c}\text { MDA level* } \\
\mu \mathrm{M} / \mathrm{l}\end{array}$ & $\frac{2.88 \pm 0.23}{\mathrm{~B}}$ & $3.26 \pm 0.42$ & - \\
\hline
\end{tabular}

\begin{tabular}{|c|c|c|c|}
\hline \multirow[b]{3}{*}{ Parameters } & \multicolumn{3}{|c|}{ V smokers aged 34-49 y } \\
\hline & \multicolumn{3}{|c|}{ Mean \pm S.D. } \\
\hline & $\begin{array}{c}\text { Control } \\
\mathbf{n}=11\end{array}$ & $\begin{array}{c}\text { Cardiovascular } \\
\text { Patients } \\
\text { n=8 } \\
\end{array}$ & $\begin{array}{l}\text { Diabetic Patients } \\
\text { n=0(not obtained) }\end{array}$ \\
\hline $\begin{array}{l}\text { LOX level in the } \\
\text { serum** U/I }\end{array}$ & $\begin{array}{c}270 \pm 25.6 \\
\mathrm{~B}\end{array}$ & $\begin{array}{c}543 \pm 39.5 \\
\mathrm{~A} \\
\end{array}$ & - \\
\hline $\begin{array}{c}\text { LOX level in the } \\
\text { blood-cells } \\
\text { homogenate*** } \\
\text { U/I } \\
\end{array}$ & $\begin{array}{c}567 \pm 140.9 \\
\text { B }\end{array}$ & $\begin{array}{c}1452 \pm 191 \\
\mathrm{~A}\end{array}$ & \\
\hline $\begin{array}{l}\text { TC level** } \\
\text { mg/100 ml } \\
\end{array}$ & $\begin{array}{c}183.3 \pm 17.9 \\
\mathrm{~B} \\
\end{array}$ & $\begin{array}{c}230 \pm 22 \\
\mathrm{~A}\end{array}$ & - \\
\hline $\begin{array}{c}\text { HDL-C level* } \\
\text { mg/100 ml }\end{array}$ & $\begin{array}{c}39.349 \pm 4.075 \\
\mathrm{~A}\end{array}$ & $\begin{array}{c}32.5 \pm 7.8 \\
\mathrm{~B}\end{array}$ & - \\
\hline TC/HDL-C* & $\begin{array}{c}4.28 \pm 0.45 \\
\mathrm{~B}\end{array}$ & $\begin{array}{c}5.26 \pm 0.95 \\
\mathrm{~A}\end{array}$ & - \\
\hline $\begin{array}{c}\text { GSH level** } \\
\mu \mathrm{M} / \mathrm{l}\end{array}$ & $\begin{array}{c}14.300 \pm 2.141 \\
\mathrm{~A}\end{array}$ & $\begin{array}{c}5.70 \pm 1.81 \\
\mathrm{~B}\end{array}$ & - \\
\hline $\begin{array}{c}\text { MDA level* } \\
\mu \mathrm{M} / \mathrm{l}\end{array}$ & $\begin{array}{c}3.4650 \pm 0.466 \\
\mathrm{~B}\end{array}$ & $\begin{array}{c}3.97 \pm 0.495 \\
\mathrm{~A}\end{array}$ & - \\
\hline
\end{tabular}




\begin{tabular}{|c|c|c|c|}
\hline \multicolumn{4}{|c|}{ VI smokers aged $\geq 50 \mathrm{y}$} \\
\hline \multirow[b]{2}{*}{ Parameters } & \multicolumn{3}{|c|}{ Mean \pm S.D. } \\
\hline & $\begin{array}{c}\text { Control } \\
\mathbf{n}=17\end{array}$ & $\begin{array}{c}\text { Cardiovascular } \\
\text { Patients } \\
\text { n=16 }\end{array}$ & $\begin{array}{l}\text { Diabetic Patients } \\
\qquad \mathrm{n}=12\end{array}$ \\
\hline $\begin{array}{l}\text { LOX level in the } \\
\text { serum** } U / 1\end{array}$ & $\begin{array}{c}494 \pm 168.3 \\
C\end{array}$ & $\begin{array}{c}711 \pm 201 \\
B\end{array}$ & $\begin{array}{c}907 \pm 342 \\
\mathrm{~A}\end{array}$ \\
\hline $\begin{array}{l}\text { LOX level in the } \\
\text { blood-cells } \\
\text { homogenate* U/l }\end{array}$ & $\begin{array}{c}1107.0 \pm 375.6 \\
\mathrm{~B}\end{array}$ & $\frac{1722 \pm 503}{\mathrm{~A}}$ & $\begin{array}{c}1976 \pm 559 \\
\mathrm{~A}\end{array}$ \\
\hline $\begin{array}{c}\text { TC level*** } \\
\text { mg/100 ml } \\
\end{array}$ & $\begin{array}{c}187.589 \pm 44 \\
\mathrm{~B} \\
\end{array}$ & $\begin{array}{c}247.6 \pm 68 \\
\mathrm{~A} \\
\end{array}$ & $\begin{array}{c}257 \pm 72 \\
\mathrm{~A}\end{array}$ \\
\hline $\begin{array}{c}\text { HDL-C level* } \\
\text { mg/100 ml }\end{array}$ & $\begin{array}{c}36.47 \pm 6.03 \\
\mathrm{~A}\end{array}$ & $\begin{array}{c}31.6 \pm 7.5 \\
\mathrm{~B}\end{array}$ & $\begin{array}{c}30.3 \pm 8.6 \\
\mathrm{~B}\end{array}$ \\
\hline TC/HDL-C* & $\begin{array}{c}4.86 \pm 0.40 \\
\mathrm{~B} \\
\end{array}$ & $\begin{array}{c}5.52 \pm 2.25 \\
\mathrm{~A}\end{array}$ & $\begin{array}{c}5.81 \pm 2.88 \\
\mathrm{~A}\end{array}$ \\
\hline $\begin{array}{c}\text { GSH level }^{* * *} \\
\mu \mathrm{M} / \mathrm{l}\end{array}$ & $\begin{array}{c}13.270 \pm 2.07 \\
\mathrm{~A}\end{array}$ & $\begin{array}{c}5.48 \pm 1.06 \\
\mathrm{~B}\end{array}$ & $4.40 \pm \frac{1.08}{\mathrm{~B}}$ \\
\hline $\begin{array}{c}\text { MDA level* } \\
\mu \mathrm{M} / \mathrm{l}\end{array}$ & $\begin{array}{c}3.8505 \pm 1.05 \\
\text { B }\end{array}$ & $\frac{4.09 \pm 1.13}{\mathrm{~A}}$ & $\begin{array}{c}4.74 \pm 1.27 \\
\mathrm{~A}\end{array}$ \\
\hline
\end{tabular}

- Abbreviations : LOX, lipoxygenase; TC, total cholesterol; HDL-C, high density lipoprotein-cholesterol; GSH, glutathaione; MDA, malondialdehyde.

- Different letters horizontally mean a significant difference at 0.05 level according to Duncan test.

- *,** and *** means that $\mathrm{P}$-values are $>0.05,>0.01$ and $>0.001$, respectively.

As shown in Table 2, the same pattern was obtained for the patients with diabetes, as well as cardiovascular disease, for all of the studied groups accept the smokers and nonsmokers groups aged 20-34 y and the smoker group aged 35-49 y because samples for these groups of patients could not be obtained. They exhibited a significant increase in the level of LOX in the serum and in the blood-cells homogenate. This result agrees with what was stated earlier; i.e. the increased expression of LOXs and then $\mathrm{LTE}_{4}$-generation were associated with diabetes. Streptozotocin-induced diabetic rats had increased urinary excretion of $\mathrm{LTE}_{4}$, then its level was decreased by insulin treatment (Kang et al., 2001). High glucose level also increased the LOX enzymes in cultured endothelial cells, VSMC, mesangial cells and glomeruli of diabetic rats (Natarajan and Nadler, 2004 ; Kang et al., 2001). Interestingly, one of a few genes that are increased in pancreatic $\beta$-cells of the insulin-resistant diabetic rates is that for LOXs (Natarajan and Nadler, 2004). In addition, Kang et al. (2001) state that the 12/15 LOX product, 12-HETE, is increased in the urine of diabetic patients, which reflects the relation between the level of LOXs and diabetic mellitus. 


\section{The Biochemical Parameters}

\section{Total cholesterol}

As shown in Table 2, there has been a significant increase in the level of total cholesterol, $\mathrm{TC}$, in the serum of patients compared with healthy subjects. This result agrees with many other previous studies (WHO report, 1994). Purushothaman et al. (2011) state that peroxisome proliferator-activated receptor alpha (PPAR $\alpha$ ) regulates genes involved in lipid metabolism, homeostasis and inflammation, in response to fatty acids and fibrates, making it a candidate gene for risk of dyslipidaemia, atherosclerosis and coronary artery disease. Various polymorphic markers that act as candidate genes are related to lipoprotein metabolism and account for variations in the level of serum TC and LDL-C (Ozturk and Killen, 1999).

\section{HDL-Cholesterol}

Table 2 exhibited a significant decrease in HDL-C in the serum of males with cardiovascular disease (with or without diabetes), whether smokers or nonsmokers.

Although the relationship between plasma HDL-C and the development of atherosclerosis is complex, it has been established that the level of plasma HDL-C is inversely proportional to the risk factor of this disease (Chapman, 2004). This establishment agrees with that obtained in the present study. It has been stated that the risk of coronary heart disease, CHD, is elevated by $3 \%$ in women and $2 \%$ in men for each $1 \mathrm{mg} / \mathrm{dL}$ decrement in the level of HDL-C than its normal level which is $44 \mathrm{mg} / \mathrm{dL}$ (Gordon et al., 1989). Nevertheless, high levels of HDL-C $(>65 \mathrm{mg} / \mathrm{dL}$ ) were shown to offer protection against CHD events even when LDL-C level was elevated above $160 \mathrm{mg} / \mathrm{dL}$ (Castelli et al., 2011).

Pirillo et al. (2008) stated that $\mathrm{HDL}_{3}$ can be modified in vitro by 15 -LOX generating a dysfunctional lipoprotein that exhibits a decrease ability to promote cholesterol efflux from lipid-laden macrophages. This modification significantly impairs the ability of $\mathrm{HDL}_{3}$ to function as an efficient cholesterol acceptor or leads to decreasing HDL-C. The modification of $\mathrm{HDL}_{3}$ (the major antiatherogenic HDL subfraction) by 15-LOX, an enzyme overexpressed in the atherosclerotic lesions, impairs the anti-inflammatory activity of this lipoprotein, and the modified $\mathrm{HDL}_{3}$ failed to inhibit induction of adhesion molecules and chemoattractants which act as mediators of monocyte adhesion to endothelial cells. This establishment demonstrates that the protective role of $\mathrm{HDL}_{3}$ against the initiation and progression of atherosclerosis of atherosclerosis is impaired (Pirillo et al., 2008).

On the other hand, it was stated that the ratio of TC/HDL-C (but not their absolute value) reflects the real risk factor related to patients with cardiovascular disease; the higher the level of TC/HDL-C, the higher the susceptibility of cardiovascular events (Kumar et al., 2009; Wang et al., 2009; Stevens et al., 2001). Therefore, the high level of this ratio for subjects with cardiovascular disease shown in the table seems to contribute to the development of this disease. 


\section{Glutathione}

As shown in Table (2), the levels of glutathione in serum of patient subjects were significantly decreased. This decrease may be attributed to the increased oxidative stress and the generation of the free oxygen radicals (ROS). Many experimental reports demonstrate that ischemia followed by reperfusion elicit a cascade of proinflammatory reactions that are known to lead to the production of ROS (Pasupathi et al., 2009 ; Raghuvanshi et al., 2005). It is well recognized that diabetes induces oxidative stress and then the accumulation of ROS which, inturn, reduce the activities of antioxidant enzymes such as catalase and superoxide dismutase. The decrease in the activities of these enzymes result in insufficient availability of GSH (Raghavan and Kumari, 2006; Powell et al., 2004). In addition, it was stated that long term exposure to high glucose decreases the expression of glutamyl cysteine ligase (the regulating enzyme for GSH synthesis) resulting in a decrease in GSH levels (Tran et al., 2004).

\section{Malondialdehyde}

Table (2) exhibited that the levels of serum MDA of patients were elevated significantly. The MDA is an important end product of lipid peroxidation, so, the increase in its level reflects the increase in free radicals (Janero, 1990). Free radicals are considered to have a great role in the pathogenesis of many diseases such as diabetes mellitus, atherosclerosis, cancer, myocardial infarction and immune diseases (Pasaoglu et al., 2004). An increase in free radical formation enhances oxidation of LDL, an important mediator of vascular injury in cardiovascular pathologlogies including hypertension, atherosclerosis and ischemia-reperfusion (Khanna et al., 2008). On the other hand, high level of glucose can increase lipid peroxidation. Hyperglycemia may stimulate autooxidtion glucose leading to free radical production in diabetics (Pasaoglu et al., 2004).

\section{ACKNOWLEDGMENT}

We would like to thank the nursing staff of Care Unit in Ibn Seena Teaching Hospital in Mousl city and the cooperation of volunteers is sincerely acknowledged.

\section{REFERENCES}

Akande, A.A.; Akinyinka, A.O. (2005). Serum malondialdehyde levels during menstral cycle. J. Bio. African, 4(11),1997-1299.

Al-Flayeh, K.A. (2000). "Introduction to Biochemistry". 2nd edn., Mosul Univ. Press, Iraq, $158 \mathrm{p}$.

AL-Zamely, O.; AL-Nimer, M.S.; AL-Muslih, R. K. (2001). Detection the level of peroxynitrite, and related with antioxidant status in the serum of patients with acute yocardial infarction. National. J. Chem., 4, 625-637.

Castelli, W.P.; Doyle, J.T.; Gordon, T; Hames, C.G.; Hgortland, M.C.; Hulley, S.B.; Kagan, A.; Zukel, W.J. (2011). HDL cholesterol and other lipids in coronary heart disease. The cooperative lipoprotein phenotyping study. J. Amer. Heart Associ, 55(5),767-72. 
Chabane, N.; Zayed, N.; Benderdour, M.; Pelletier, J.M.; Pelletier, J.P.; Duval, N.; Fahmi, H. (2009). Human articular chondrocytes express 15-lipoxygenase-1 and -2 : potential role in osteoarthritis. Arthri. Research and thera., 11, 44-49.

Chapman, M. J. (2004). "Are the Effects of Statins on HDL-cholesterol Essenentials of Medicine Structure and Function of Normal Heart and Blood Vessels". 5th edn. W. B. Saunders Company, Philadelphia, New York., pp.21-23.

Christenson, R.H.; Gregory, L.C.; Johnson, L.J. (2001). "Outline Review Clinical Chemistry", McGraw-Hill Companies, New York, USA, pp. 87-88.

Gordon, D.J.; Probstfield, J.L.; Garrison, R.J.; Garcia-Palmieri, M.R.; Kagan, A.; Kannel, W.B.; Schiffman, J. (1989). High density lipoprotein cholesterol and cardiovascular disease. Four prospective American studies. Circulation, 79, 8-15.

Helgadottir, A.; Manolescu, A.; Thorleifsson, G. (2004). The gene encoding 5-lipoxygenase activating protein confers risk of myocardial infarction and stroke. Nat. Genet., 36, 233-239.

Huo, Y.; Zhao, L.; Hyman, M. C.; Shashkin, P.; Harry, B.L.; Burcin, T.; Forlow, B.; Stark, M.A.; Smith, D.F.; Clarke, S.; Srinivasan, S.; Hedrick, C.C.; Pratico, D.; Witztum, J.L.; Nadler, J.L.; Funk, C.D.; Ley, K. (2004). Critical role of macrophage $12 / 15-$ lipoxygenase for atherosclerosis in apolipoprotein E-deficient mice. Circulation, 110, 2024-2031.

Imig, J.D. (2006). Eicosanoids and renal vascular function in diseases. Clin. Sci., 111, 21-34.

Janero, D. E. (1990). Malondialdenyde and thiobarbituric acid-reactivity as diagnostics indices of lipid preoxidation and peroxidative tissue injurny". Free Radical Biol. Med., 9(6), 515-540.

Jawien, J.; Korbut, R. (2010). The current view on the role of leukotrienes in atherogenesis. $J$. Physiol. Pharmacol., 61(6), 647-650.

Kang, S. W.; Alder, S. G.; Nast, S. G. (2001). 12-Lipoxygenase is increased in glucosestimulated mesangial cells and in experimental diabetic nephroparthy. Kidney. Int., 59, 1354-1362.

Kayama, Y.; Minamino, T.; Toko, H.; Sakamoto, M.; Shimizu, I.; Takahashi, H.; Okada, S.; Tateno, K.; Moriya, J.; Yokoyama, M.; Nojima, A.; Yashimura, M.; Egashira, K.; Aburatani, H.; Komuro, I. (2009). Cardia 12/15-lipoxygenase- induced inflammation is involved in heart failure. J. Exper. Medic., 206(7), 1565-74.

Khanna, H. D.; Sinha, M. K.; Khanna, S.; Tandon, R. (2008). Oxidative stress in hypertension : association with antihypertensive treatment. Ind. J. Physiol. Pharmacol., 52(3), 283287.

Kuhn, H.; Belkner , J.; Wiesner, R.; Schewe, T.; Lankin, V.Z.; Tikhaze, A.K.(1992). Structure elucidation of oxygenated lipids in human atherosclerotic lesions. Eicosanoids, 5, 17.

Kumar, A.; Nagtilak, S.; Sivakanesan, R.; Gunasekera, S. (2009). Cardiovascular risk factors in elderly normolipidemic acute myocardial infarct patients- acase controlled study from India. J. Trop. Med. Public-Health, 40(3), 581-592.

Lowenstein, J. M. (1981). "Methods in Enzymology". Academic press, INC. New York, pp. 435-436. 
Maskrey, B.H.; O’Donell, V.B. (2008). Analysis of eicosanoids and related lipid mediators using mass spectroscop. Biochem. Soc. Trans., 36(5),1056-59.

McKee, T.; McKee, J.R. (1996). "Biochemistry, an Introduction". Wm. C. Brown Publishers, Boston, USA, pp. 115-129.

Murphy, R. C.; Gljon, M. A. (2007). Biosynthesis and metabolism of leukotrienes. Biochem. J., 405, 379-395.

Natarajan, R.; Nadler, J. L. (2004). Lipid inflammatory mediators in diabetic vascular disease. Arterioscler. Thromb. Vasc. Biol., 24, 1542-1548.

Novgorodtseva, T.P.; Karaman, Y.K.; Zhukova, N.V.; Lobanova, E.G.; Antonyuk, M.V.; Kantur, T.A. (2011).Composition of fatty acids in plasma and erythrocytes and eicosanoids level in patients with metabolic syndrome. Lip. Hea. Dis., 10(82), 118696.

Ozturk, I.C.; Killen, A.A. (1999). An overview of genetic factors influencing plasma lipid levels and coronary artery disease risk. Archi. Patho. and Labor. Medi., 123(12), 1219-22.

Pasaoglu, H.; Sancak , B.; Bukan, N. (2004). Lipid peroxidation and resistance to oxidation in patients with type 2 diabetes Mellitus. J. Exp. Med. Tohoku., 203, 211-218.

Pasupathi, P.; Rao, Y.Y.; Farook, J.; Saravanan, G.; Bakthavathsalam, G. (2009). Oxidative stress and cardiac biomarkers in patients with acute myocardial infarction. Eur. J. Sci. Res., 27(2), 275-285.

Pirillo, A.; Uboldi, P.; Bolego, C.; Kuhn, H.; Catapano, A.L. (2008). The 15-lipoxygenaseModified high density lipoxygenase 3 fail to inhibit the TNF- $\alpha$-induced inflammatory response in human endothelial cells. J. Immunol., 181, 2821-2830.

Powell, L. A.; Warpeha, K. M. ; Xu, W.; Walker, B.; Trimble, E.R. (2004). High glucose decreases intacellular glutathione concentrations and upregulates inducible nitric oxide synthase gene expression in intestinal epithelial cells. J. Molecular Endocrinology, 33, 797-803.

Purushothaman, S.; Ajitkumar, V.K.; Nair, R. R. (2011). Association of PPAR $\alpha$ intron 7 polymorphism with coronary artery disease: a cross-sectional study. ISRN. Cardiology. Article ID 816025, 4 pages.

Radmark, O.; Werz, O.; Steinhilber, D.; Samuelsson, B. (2007). 5-lipoxygenase : regulation of expression and enzyme activity. Trends in Biochem. Sci., 32(7), 332-341.

Raghavan, B.; Kumari, S. K. (2006). Effect of terminalia arjuna stem bark on antioxidant status in liver and kidney of alloxan diabetic rats. Ind. J. Physiol. Pharmacol., 50(2), 133142.

Raghuvanshi, R.; Chandra, M.; Misra, P. C.; Misra, M.K. (2005). Effect of vitamin on the platelet xanthine oxidase and lipid peroxidation in the patients of myocardial infarction. Ind. J. Clin. Bio., 20(1), 26-29.

Rapoport, S. M.; Schewe, T.; Wiesner, R. R.; Halangk, W.; Ludwig, P.; Janicke-Hohne, M.; Tannert, C.; Hiebsch, C.; Klatt, D. (1979). The lipoxygenase of reticulocytes. Eur. J. Biochem., 99, 545-561. 
Riendeau, D.; Falgueyret, J. P.; Guay, J. (1991). Pseudoperoxidase activity of 5-lipoxygenase stimulated by potent benzofuranol and N-hydroxyurea inhibitors of the lipoxygenase reaction. Biochem. J., 274, 287-292.

Rouzer, C.A.; Samuelsson, B. (1985). One the nature of the 5-lipoxygenase reaction in human leukocytes : Enzyme purification and requirement for multiple stimulatory factors. Proc. Natl. Acad. Sci. USA (Biochemistry), 82, 6040-44.

Scharcterle, G. R.; Pollack, R. L. (1973). Asimplified method quantitative assay for small amounts of proteins in biological materials. Anal. Biochem., 51, 645-655.

Spanbrock, R.; Grabner, R.; Lotzer, K. et al (2003). Expanding expression of the 5lipoxygenase pathway within the arterial wall during human atherogenesis. PNAS, 100 (3), 1238-43.

Stevens, R. J.; Kothari, V.; Adler, A. I.; Stratton, I.M.; Holman, R.R. (2001). The UKPDS risk engine : a model for the risk of coronary heart disease in type 11 diabetes (UKPDS 56). Clin. Sci., 101, 671-679.

Tran, P. O. T.; Parker, S. M. ; Leroy, E. ; Franklin, C.C.; Kavanagh, T.J.; Zhang, T.; Zhou, H.; Vliet, P.; Oseid, E.; Harmon, J.S.; Robertson, R.P.(2004). Adenoviral over expression of the glutamylcystein ligase catalytic subunit protects pancreatic islets against oxidative stress". J. Biol. Chem. USA., 279(52), 53988-53993.

WHO report, (1994). Fat and oils in human nutrition report of joint expert consultation FAO rome. FAO. Food. Nut., 57.

Williams, M.; Harwood, J. L. (2000). Characterization of lipoxygenase isoforms in olive callus cultures. Biochem. Soc. Trans., 28(6), 830-831. 